\title{
OTENTIFIKASI AKTA NOTARIL DALAM PEMBUATAN AKTA BERDASARKAN SISTEM ONLINE
}

\section{THE AUTHENTIFICATION OF NOTARIAL DEED IN MAKING CHERTIFICATE BASED ON ONLINE SYSTEM}

Tusmiati

Jurnal Living Law, Vol. 13, No. 1,

2021

hlm. 57-62

\begin{abstract}
The aim of the reasearch are: 1) To know and to analyze the law system in making notarial deeds generally related to digital era. 2) To know and to analyze the development model of notarial deed authentification in its signing stage in the digital era. The methodology applied in the research is juridical normative approach whereby objectively explaining particular data followed by an analysis based on legal theory and related statutes of research objects. The result of the research were: 1) The making certificates digitally, only can be used in a newsworthy event of a meeting in a company deed. 2) In making general notarial deeds we still have to deal with a notary directly which is based on Notarial Law. 3)The development model of notarial deed in its signing stage in the digital era hasn't had a compatibility between the Law of Notary Position and Electronic and Information Transaction Law; which resulted in inhabiting of notary's authority. The recent regulations have not fulfiled people's need. Due to there is no legal certainty, one day, there will be a problem that can not be anticipated.
\end{abstract}

Keywords : Authentification; Notarial Deed; Online System.

\begin{abstract}
Abstrak : Penelitian ini mempunyai tujuan yaitu 1) Untuk mengetahui dan menganalisa sistem hukum pembuatan akta notaris pada umumnya dikaitkan dengan era digital 2) Untuk mengetahui dan melakukan analisis model pengembangan otentifikasi akta notaris dalam penandatanganan di era digital. Adapun metode yang dipergunakan adalah metode pendekatan secara Yuridis Normatif, artinya menjelaskan secara objek atau terperinci suatu data, kemudian mengananalisisnya berdasarkan teori hukum serta perundang-undangan yang berkaitan dengan objek penelitian. Hasil dari penelitian ini yaitu : 1) pembuatan akta secara digital baru dapat dipergunakan dalam berita acara rapat dalam suatu akta PT. Untuk akta notaris pada umumnya masih mewajibkan berhadapan dengan Notaris langsung sesuai dengan peraturan perundang-undangan Jabatan Notaris. 2) Model pengembangan akta notaris dalam penanadatanganan di era digital belum ada kesesuaian antara UUJN dan UU ITE berakibat menghambat kewenangan notaris yang belum sepenuhnya terpenuhi, aturan hukum yang ada pada saat ini belum mampu memenuhi keinginan masyarakat. Karena belum adanya kepastian hukum maka jika suatu hari nanti ada permasalahan belum bisa diantisipasi.
\end{abstract}

Kata Kunci : Otentifikasi; Akta Notaril; Online sistem.

\section{PENDAHULUAN}

Indonesia yang berada dalam era globalisasi ditandai dengan era teknologi informatika yang memperkenalkan dunia maya (cyberspace, virtual world) dengan menggunakan jaringan yang dinamakan internet, komunikasi dengan media elektronik tanpa kertas. Melalui jaringan elektronik ini maka orang tersebut akan 
memasuki dunia serba canggih atau era digital yang bersifat abstrak, universal, beserta perbedaan dari tempat dan waktu. ${ }^{1}$

Perkembangan dari ilmu Pengetahuan serta teknologi yang kian hari semakin baik dan sangat pesat perkembangannya. Hal ini karena manusia selalu berinovasi untuk menghasilkan karya yang lebih baik dalam mengembangkan ilmu pengetahuan sesuai bidang ilmu yang dimiliki dan ditekuni sehingga bermanfaat.

Ramainya tentang berbagai kejahatan secara elektronik (cyber crime) mengakibatkan terdorongnya masyarakat dalam penggunaan digital signature. Kini, Menteri Komunikasi dan Informatika sangat giat menerapkan dan melakukan penyuluhan terhadap tanda tangan digital untuk melakukan transaksi online. Dengan harapan, dengan adanya teknologi ini, masyarakat bisa melakukan berbagai kegiatan secara daring.

Transaksi elektronik yang sifatnya non face (tanpa bertatap muka), non sign (tidak menggunakan tanda tangan asli/tandatangan basah) dan tanpa batas daerah (orang tersebut dapat melakukan Transaksi elektronik satu orang dengan orang lain walaupun mereka berada di kota ataupun Negara yang jauh) dengan memakai media elektronik baik Handphone atau Laptop.

Indonesia mempunyai aturan hukum untuk mengatur masalah tersebut dengan dikeluarkannya UU Nomor 19 Tahun 2016 tentang Perubahan atas UU Nomor 11 Tahun 2008, tentang "Informasi dan Transaksi Elektronik" (UU ITE). Berdasarkan pada Pasal 18 juncto Pasal 7 juncto Pasal 11 Undang-undang Nomor 19 Tahun 2016 tentang Perubahan atas Undang-Undang Nomor 11 Tahun 2008 sehingga kekuatan pembuktian yang sempurna dalam dokumen elektronik tersebut yang ditandatangani menggunakan digital signature sama

1 Mariam Darus Badrulzaman, Mendambakan Kelahiran Hukum Saiber ( Cyber Law) di Indonesia, Medan, 2001, HIm. 3 dengan kekuatan pembuktian akta otentik itu sendiri yang dibuat oleh notaris.

Pada pasal 11 Undang-Undang Informasi dan Transaski Elektronik membahas tentang tandatangan elektronik yang mana Undang-Undang ini memberikan menegaskan bahwa walaupun hanya merupakan suatu kode, tanda tangan Elektronik akan tetapi memiliki kekuatan yang sama dengan tanda tangan manual dan memiliki kekuatan hukum beserta akibat hukumnya.

Berdasakan Undang-Undang Nomor 2 Tahun 2014 tentang Jabatan Notaris atau biasa disingkat dengan UUJN, dapat diketahui bahwa notaris mempunyai peran dan fungsi yang sangat penting dalam suat legalitas transaksi di Indonesia, dan malahan notaris juga diketahui sebagai pihak ketiga yang dapat dipercaya. Jasajasa notaris telah menjadi kebutuhan rakyat umum, tidak hanya dalam membuat akta, akan tetapi sebagai saksi atau penengah dari transaksi transaksi yang dilakukan. ${ }^{2}$

Perkembangan informasi di era digital seperti ini merupakan tantangan tersendiri akan tetapi dapat juga menjadi bumerang untuk jabatan notaris. Hal tersebut dikarenakan ada hal-hal yang demi efisiensi tidak memerlukan sarana kertas (paperless), akan tetapi ada suatu hal-hal khusus yang harus tetap dipertahankan yaitu pemakaian kertas (antara lain adalah akta otentik yang dibuat di hadapan atau oleh Notaris).

Berkaitan dengan penggunaan teknologi informasi, terdapat dalam Pasal 77 UU Nomor 40 Tahun 2007 tentang PT juga memberikan pengaturan mengenai kemungkinan para pemegang saham melakukan rapat menggunakan media webinar, video konferensi, zoom, dan media elektronik lainnya sesuai dengan perkembangan zaman. Rapat tersebut dilakukan dengan syarat yang memuat

2 Edmon Makarim, Notaris Dan Transaksi Elektronik Kajian Hukum Tentang Cybernotary Atau Elektronik Notary, PT Raja Grafindo Persada, Jakarta, 2014, Hlm. 6 
semua peserta rapat saling melihat mendengar secara langsung, beserta bisa ikut ambil bagian dalam rapat tersebut. Penyelenggaraan rapat dengan menggunakan media tersebut harus dibuatkan risalah rapat yang mendapat persetujuan dan ditandatangani oleh para peserta rapat. Penjelasan dari pasal tersebut mengatakan bahwa yang dimaksud dengan "disetujui dan ditandatangani" adalah ditandatangani secara fisik atau secara elektronik.

Kehidupan notaris adalah kolaborasi antara teori dan praktik didalam tataran yang pas antara teori beserta praktik seiring sejalan atau malah terkadang tidak, maksudnya tidak selalu teori mendukung pada proses prakteknya, maka kehidupan notaris harus dimulai dengan tidak hanya diambil dan dikembangkan oleh teori-teori ilmu hukum yang sudah ada terlebih dahulu, kan tetapi notaris harus juga berinovasi sendiri dengan teori-teori tersebut untuk menunjang dalam mengemban tugas jabatan notaris dan pengalaman-pengalaman selama menjalankan tugas sebagai notaris. ${ }^{3}$

Dalam praktiknya, mengenai tanda tangan elektronik, masih ada beberapa masalah yang berhubungan dengan kewajiban notaris sebagai pejabat yang berwenang mengesahkan berbagai akta, yang juga salah satu lainnya adalah membacakan kata perkata akta yang dibuatnya, Kemudian, ada pula pengaturan yang dapat dijadikan sebagai landasan hukum pembuatan akta secara elektronik dalam Undang-undang Nomor 19 Tahun 2016 tentang Perubahan Atas Undangundang Nomor 11 Tahun 2008 tentang Informasi dan Transaksi Elektronik (UU ITE), dimana Undang-undang ini secara tegas memberikan pembatasan terhadap kewenangan notaris dalam pembuatan akta secara elektronik, sebagaimana dapat dilihat dalam Pasal 5 ayat (4) UU ITE.

3 Emma Nurita, Cybenotary Pemahaman Awal dan Konsep Pemikiran, Refika Aditama, Jakarta, 2014, Hlm.2.
Pemanfaatan teknologi informasi yang canggih di dalam pembuatan akta notaris secara elektronik tidak saja memberikan keuntungan, tapi juga terdapat berbagai pemasalahan. Keuntungan yang didapat dari pembuatan akta tersebut yaitu antara lain adalah hemat waktu, uang dan tenaga. Hanya saja pemanfaatan teknologi informasi di samping menghasilkan banyak manfaat bagi masyarakat, juga menimbulkan beberapa persoalan yang khususnya menyangkut persoalan hukum.

\section{METODE PENELITIAN}

Metode penelitian yang digunakan adalah pendekatan yuridis normatif, adalah hukum dikonsepkan sebagai norma, kaidah, asas atau dogma-dogma. Pendekatan yuridis normatif dikenal pula dengan istilah pendekatan/penelitian doktrinal atau penelitian hukum normatif. Tahap penelitian yuridis normatif, menggunakan studi kepustakaan (penelaah terhadap literatur), namun sepanjang diperlukan, dapat dilakukan interview, untuk melengkapi studi kepustakaan. Termasuk ke dalam kajian/pendekatan yuridis normatif di antaranya adalah sejarah hukum dan pembandingan hukum, juga filsafat hukum. Dalam penelitian bahan pustaka merupakan data dasar penelitian yang digolongkan sebagai data sekunder. ${ }^{4}$

\section{PEMBAHASAN}

Dunia notaris adalah kolaborasi antara teori dan praktik dalam tataran yang pas dan sesuai antara teori dan praktik seiring sejalan atau kadang-kadang tidak sejalan. Pemanfaatan teknologi informasi untuk pembuatan akta notaris menggunakan media elektronik tentu tidak hanya memberikan keuntungan semata,

4 Martin Roestamy (et al), Metode Penelitian, Laporan, dan Penulisan Karya Ilmiah Hukum Pada Fakultas Hukum, Fakultas Hukum Universitas Djuanda, Bogor, 2015, Hlm. 49. 
akan tetapi juga menimbulkan beberapa permasalahan. Keuntungan yang berkaitan dengan pembuatan secara elektronik, yaitu hemat waktu, biaya dan tenaga.

Adapun masalah yang akan timbul dalam prakteknya secara elektronik yaitu dengan adanya suatu kwajiban- kewajiban yang harus laksanakan oleh notaris terhadap akta yang dibuatnya tersebut, sebagaimana dituangkan dalam Pasal 16 ayat (1) UUJN, khususnya Pasal 16 ayat (1) UUJN huruf $\mathrm{c}$, dan $\mathrm{m}$, yang selengkapnya berbunyi:

1. Melekatkan surat dan dokumen beserta sidik jari penghadap pada Minuta Akta;

2. Membacakan Akta di hadapan penghadap dengan dihadiri minimum 2 (dua) orang saksi, ataupun 4 (empat) yang secara khusus untuk membuat akta wasiat di bawah tangan, dan/atau ditandatangani juga pada waktu yang bersamaan oleh para penghadap, saksi, dan notaris itu sendiri.

Oleh karena itu berdasarkan uraian kedua bentuk jenis akta umum yang dibuat oleh notaris, untuk saat ini sangat tidak dimungkinkan menerapkan teknologi informasi dalam pembuatan akta notaris menggunakan sistem elektronik. Dalam hal ini, kehadiran notaris di hadapan para pihak yang membuat akta adalah suatu keharusan sehingga dapat dibuat berita acara yang isinya uraian notaris yang dapat dilihat dan disaksikan oleh notaris ataupun atas permohonan pihak-pihak yang membuatnya.

Teknologi Informasi diyakini akan menjadi alternatif utama bagi penyelenggaraan kegiatan bisnis $(e-$ business), maupun pemerintahan $(e-$ goverment) yang selama ini dan dimasa lalu lebih dijalankan di dunia maya (the real world). ${ }^{5}$

Akan tetapi, substansinya hukum dalam pembuatan akta secara elektronik

5 M. Arsyad Sanusi, Hukum dan Teknologi Informnasi, Tim Kemas Buku, Bandung, 2001, HIm, 3 belum terakomodir seutuhnya dalam UUJN dan juga UU ITE yang merupakan landasan hukum bagi notaris untuk melihat peluang pembuatan akta secara elektronik sesuai dengan keinginan dan perkembangan masyarakat modern pada zaman sekarang. Namun, walaupun demikian di dalam UUJN, KUH Perdata dan UU ITE, pembuatan akta tersebut belum memungkinkan untuk dilaksanakan oleh notaris, akan tetapi ada celah pembuatan akta tersebut tetap ada yaitu dengan adanya peraturan dengan pembuatan akta secara elektronik didalam RUPS melalui media telekonferensi (RUPS Telekonferensi) dan video Call ataupun Zoom. Hanya di dalam proses praktiknya belum dapat diterapkan secara maksimal, mengingat adanya berbagai kendala yuridis dihadapi oleh pejabat yang berwenang dan notaris.

RUPS (Rapat Umum Pemegang Saham), dilakukan dalam Undang-undang Perseroan Terbatas, dalam pasal 77 yang merupakan tanda hukum yang menunjukkan peluang bagi notaris dalam pembuatan akta secara elektronik, namun ketentuan ini tidak memiliki sinkronisasi hukum dengan substansi UU ITE yang muncul belakangan. Pembuat undangundang bukannya lebih mempertegas kewenangan notaris dalam UU ITE, tetapi sebaliknya membatasi kewenangan notaris dalam membuat akta secara elektronik. Padahal pelayanan singkat serta cepat adalah suatu kepuasan bagi para masyarakat.

Pembuatan Akta Notaris dalam pelaksanaan RUPS melalui telekonferensi dalam rangka perubahan Anggaran Dasar Perseroan Terbatas dapat dilakukan dengan menggunakan 2 cara yaitu Akta yang dibuat langsung oleh notaris dalam bentuk Akta Berita Acara atau Akta Relaas (ambtelijke akten) dan Akta Pernyataan Keputusan Rapat (partij akten). ${ }^{6}$ Pelaksanaan RUPS melalui telekonferensi guna perubahan Anggaran Dasar Perseroan Terbatas dibuat ke dalam Akta Pernyataan

6 https://www.hukumonline.com Diakses tanggal 10-12-2019, Pukul 22.30 WIB 
Keputusan Rapat (partij akten), maka pembuatan Akta Pernyataan Keputusan Rapat dilakukan dengan memberi kuasa kepada salah seorang yang hadir dalam rapat untuk membuat dan menyatakan kembali risalah rapat di hadapan Notaris. Pembuatan Akta PKR (partij akten) tidak mempunyai permasalahan yang muncul karena pembuatan Akta Notaris dilakukan dengan konvensional.

Oleh sebab itu, untuk menciptakan hukum yang pasti dan manfaat hukum untuk masyarakat, perlu adanya keseragaman peraturan perundangundangan yang berhubungan dengan kewenangan notaris didalam pembuatan akta secara elektronik, adalah antara UUJN dengan UU ITE beserta antara UUPT dengan UUJN. Oleh karenanya notaris tidak akan mengalami problem yuridis yang menyangkut kewenangannya dalam pembuatan akta yang dilakukan secara elektronik. Serta masyarakat itu sendiri yang membutuhkan jaminan akan perbuatan hukum yang dilakukan menggunakan media elektronik hanya dapat dicapai dengan terakomodirnya kewenangan notaris di dalam pembuatan akta secara elektronik dalam peraturan undang-undang yang berlaku.

\section{KESIMPULAN}

1. Dalam hal praktiknya saat ini Notaris baru bisa menerapkan pembuatan secara online itu hanya pada pembuatan Berita Acara Rapat PT, itupun masih jarang dilakukan, karena secara umum Notaris belum bisa menerapkan media online dalam pembuatan aktanya secara elektronik ataupun transaski yang berhubungan dengan notaris secara sempurna, karena belum ada landasan hukum yang akurat, aturan undang-undang yang belum berjalan serta belum adanya kepastian hukum atas perbuatan hukum tersebut. Karena belum adanya sinkronasi antara UUJN dan UU ITE. Karena berhubungan dengan notaris yang diwajibkan berhadapan secara langsung dan ada dua orang saksi. Terkait pembatasan yang dilakukan untuk notaris oleh UU ITE, maka bukan termasuk alat bukti yang sah menurut UU ITE, sehingga mempersulit Pejabat umum atau notaris itu dalam praktek pembuatan akta dengan media elektronik untuk saat ini. Secara hukum belum memberikan manfaat yang hakiki terhadap notaris dan masyarakat itu sendiri.

2. Belum ada kesesuaian antara UUJN dan UU ITE berakibat menghambat kewenangan notaris yang belum sepenuhnya terpenuhi, aturan hukum saat ini belum mampu memenuhi keinginan masyarakat. Karena belum adanya kepastian hukum maka jika suatu hari nanti ada permasalahan belum bisa diantisipasi. Dan budaya kita yang lebih senang berkumpul bersama-sama dan berhadapan langsung secara fisik sedikit susah untuk melakukan secara daring. Dan notaris sendiri masih belum bisa menguasai sepenuhnya Teknologi dan Informasi (IT) secara maksimal.

\section{SARAN}

1. Untuk menyambut era digital ini dengan menyiapkan sarana dan prasarana yang lebih modern, serta diadakan seminar-seminar, himbauan secara berkala terhadap masyarakat, sehingga pelayanan tidak memperlambat pekerjaan, dan penumpukan orang yang akan mengakibatkan kejadian yang tidak diinginkan dan sistem tetap berjalan sebagaimana mestinya.

2. Perlu adanya revisi terhadap Undangundang Jabatan Notaris (UUJN) dan Undang-undang ITE, sehingga terdapat keseragaman dan kecocokan antara Undang-undang yang dibuat dengan dengan kekuatan otensitas akta itu sendiri. Sehingga bisa menjadikan akta 
tersebut memiliki bukti yang sah dan sempurna dimata hukum.

\section{DAFTAR PUSTAKA}

Edmon Makarim, Notaris Dan Transaksi Elektronik Kajian Hukum Tentang Cybernotary Atau Elektronik Notary, PT Raja Grafindo Persada, Jakarta, 2014

Emma Nurita, Cybenotary Pemahaman Awal dan Konsep Pemikiran, Refika Aditama, Jakarta, 2014

Mariam Darus Badrulzaman, Mendambakan Kelahiran Hukum Saiber ( CyberLaw) di Indonesia, Medan, 2001

M.Arsyad Sanusi, Hukum dan Teknologi Informasi, Tim Kemas Buku, Bandung, 2001

Martin Roestamy (et al), Metode Penelitian, Laporan, dan Penulisan Karya Ilmiah Hukum Pada Fakultas Hukum, Fakultas Hukum Universitas Djuanda, Bogor, 2015

https://www.hukumonline.com (diakses pada Tanggal: 03 November 2020) 